\title{
Physiological amyloid-beta clearance in the periphery and its therapeutic potential for Alzheimer's disease
}

\author{
Yang Xiang ${ }^{1}$ Xian-Le Bu ${ }^{1}$ Yu-Hui Liu ${ }^{1} \cdot$ Chi Zhu $^{1} \cdot$ Lin-Lin Shen ${ }^{1}$. \\ Shu-Sheng Jiao ${ }^{1}$ Xiao-Yan $\mathrm{Zhu}^{2} \cdot$ Brian Giunta $^{3} \cdot$ Jun Tan $^{4} \cdot$ Wei-Hong Song ${ }^{5}$. \\ Hua-Dong Zhou ${ }^{1} \cdot$ Xin-Fu Zhou $^{6} \cdot$ Yan-Jiang Wang ${ }^{1}$
}

Received: 31 July 2015 / Revised: 27 August 2015 / Accepted: 5 September 2015 / Published online: 12 September 2015

(c) The Author(s) 2015. This article is published with open access at Springerlink.com

\begin{abstract}
Amyloid-beta $(\mathrm{A} \beta)$ plays a pivotal role in the pathogenesis of Alzheimer's disease (AD). The physiological capacity of peripheral tissues and organs in clearing brain-derived $A \beta$ and its therapeutic potential for $\mathrm{AD}$ remains largely unknown. Here, we measured blood $A \beta$ levels in different locations of the circulation in humans and mice, and used a parabiosis model to investigate the effect of peripheral $\mathrm{A} \beta$ catabolism on $\mathrm{AD}$ pathogenesis. We found that blood $A \beta$ levels in the inferior/posterior vena cava were lower than that in the superior vena cava in both humans and mice. In addition, injected ${ }^{125}$ I labeled $A \beta 40$ was located mostly in the liver, kidney, gastrointestinal tract, and skin but very little in the brain; suggesting that $\mathrm{A} \beta$ derived from the brain can be cleared in the periphery. Parabiosis before and after $A \beta$ deposition in the brain significantly reduced brain $A \beta$ burden without alterations in the expression of amyloid precursor protein, $A \beta$ generating
\end{abstract}

Y. Xiang, X.-L. Bu and Y.-H. Liu contributed equally to this work.

Electronic supplementary material The online version of this article (doi:10.1007/s00401-015-1477-1) contains supplementary material, which is available to authorized users.

Yan-Jiang Wang

yanjiang_wang@tmmu.edu.cn

1 Department of Neurology and Centre for Clinical Neuroscience, Daping Hospital, Third Military Medical University, 10 Changjiang Branch Road, Yuzhong District, Chongqing, China

2 Department of Laboratory Medicine, Southwest Hospital, Third Military Medical University, Chongqing, China

3 Neuroimmunology Laboratory, Department of Psychiatry and Behavioral Neurosciences, Morsani College of Medicine, University of South Florida, Tampa, FL, USA and degrading enzymes, $\mathrm{A} \beta$ transport receptors, and $\mathrm{AD}$ type pathologies including hyperphosphorylated tau, neuroinflammation, as well as neuronal degeneration and loss in the brains of parabiotic AD mice. Our study revealed that the peripheral system is potent in clearing brain $A \beta$ and preventing $\mathrm{AD}$ pathogenesis. The present work suggests that peripheral $\mathrm{A} \beta$ clearance is a valid therapeutic approach for $\mathrm{AD}$, and implies that deficits in the $\mathrm{A} \beta$ clearance in the periphery might also contribute to $\mathrm{AD}$ pathogenesis.

Keywords Alzheimer's disease $\cdot$ Parabiosis $\cdot$ Amyloidbeta $\cdot$ Clearance $\cdot$ Liver $\cdot$ Kidney $\cdot$ Periphery

\section{Introduction}

Alzheimer's disease (AD) is the most common form of dementia among the elderly. Senile plaques containing amyloid-beta protein $(\mathrm{A} \beta)$ in the brain are a pathological hallmark of $\mathrm{AD}$ and they play a pivotal role in $\mathrm{AD}$ pathogenesis. The steady-state level of $A \beta$ in the brain is determined by the balance between $A \beta$ production and its clearance [47]. In the brain, $A \beta$ can be cleared via microglial

4 Rashid Laboratory for Developmental Neurobiology, Silver Child Development Center, Department of Psychiatry and Behavioral Neurosciences, Morsani College of Medicine, University of South Florida, Tampa, FL, USA

5 Townsend Family Laboratories, Department of Psychiatry, The University of British Columbia, Vancouver, BC, Canada

6 School of Pharmacy and Medical Sciences and Sansom Institute, University of South Australia, Adelaide, SA, Australia 
phagocytosis and proteolytic degradation by enzymes such as neprilysin (NEP) and insulin-degrading enzyme (IDE) [47]. Transport of $A \beta$ from the brain into the peripheral blood has been demonstrated in both animal models and humans $[28,36]$. There are several potential pathways for the efflux of brain $A \beta$ into the periphery. These include transport across the blood-brain barrier (BBB) mediated by low-density lipoprotein receptor-related peptide 1 (LRP1) [39], drainage from interstitial fluid (ISF) into cerebrospinal fluid (CSF) via perivascular [35] or glymphatic pathways [15], reabsorption from CSF into the venous blood via arachnoid villi [40] and blood-CSF barrier [32], or into the lymphatic system from the perivascular and perineural spaces $[15,34]$, and possibly via meningeal lymphatic vessels [15, 27] (see review in [41]). However, whether brain-derived $A \beta$ is physiologically catabolized in the peripheral tissues and organs, and the therapeutic potential of this peripheral $\mathrm{A} \beta$ catabolism for $\mathrm{AD}$, remains largely unknown. In the present study, we investigated the physiological catabolism of brain-derived $A \beta$ in the periphery, and examined its therapeutic potential for AD using a model of parabiosis between transgenic $\mathrm{AD}$ mice and their wild-type littermates.

\section{Materials and methods}

\section{Participants and blood sampling}

The human study was approved by the Institutional Review Board of Daping hospital affiliated to Third Military Medical University. Informed consent was obtained from all individual participants included in the study. This study recruited 30 patients with atrioventricular reentrant tachycardia (AVRT) (left accessory pathways) who underwent radiofrequency catheter ablation (RFCA). Participants had an average age of 49.5 years (19-74 years) and included 17 males and 13 females, without cognitive impairment or dementia based on the clinical assessment. To measure the catabolism of $A \beta$ in the periphery, we used time-matched arterial and venous peripheral blood samples as described previously [36]. Once the patients were deemed to undergo RFCA, catheters were placed in the left subclavian vein (SV), right femoral vein (FV), and right femoral artery (FA) simultaneously. Blood was collected from superior vena cava (SVC), inferior vena cava (IVC) proximal to hepatic vein (HV), the right FV and FA within 5 min (Fig. 1b). Five milliliters of blood were collected in vacuum blood tubes with anticoagulants at each site from the catheters. Blood was placed on ice immediately after sampling, and plasma was separated within $2 \mathrm{~h}$ and stored in polypropylene eppendorf tubes at $-80{ }^{\circ} \mathrm{C}$ for further use. To avoid the influence of diurnal changes of $A \beta$ levels, all the blood sampling were performed between 8:30 and 9:30 in the morning.
In a parallel animal study, the APPswe/PS1dE9 mouse model of AD (AD mice, Jackson Laboratories, Bar Harbor, MA) was used. This mouse model harbors the human amyloid precursor protein (APP) gent containing Swedish mutant and human presenilin 1 (PS1) gene encoding the deleted exon 9 mutation under control of mouse PrP promoter which directs the transgene expression predominantly in brain neurons [18], and develops amyloid plaques at 6 months of age [17]. Blood was sampled from the jugular vein $(\mathrm{JV})$, abdominal aorta (AA), and posterior vena cava (PVC) of female APPswe/PS1dE9 mice aged 6 months $(n=10)$ following approval by the Third Military Medical University Animal Welfare Committee. Blood was sampled within $5 \mathrm{~min}$ at each site. The sampling was performed during 8:30-9:30 in the morning. Blood samples were examined for $A \beta 40$ and $A \beta 42$ levels following our protocols as described previously [3].

\section{Analysis for biodistribution of ${ }^{125} \mathrm{I}-\mathrm{A} \beta 1-40$}

The radiolabelling of $\mathrm{A} \beta 1-40$ was performed following previous protocols [8]. Synthetic A $\beta 1-40$ was iodinated with $\mathrm{Na}^{125} \mathrm{I}$ (specific activity $37 \mathrm{MBq} / \mathrm{mg}$, China Institute of Atomic Energy) using the Iodogen technique (Pierce). Radioiodinated $\mathrm{A} \beta 1-40$ was separated from free iodine using a size exclusion column (Sephadex G-25, Pharmacia). The specific activity of radioiodinated $A \beta 1-40$ was $1.065 \mathrm{MBq} / \mu \mathrm{g}$. The radiochemical purity was $>95 \%$ trichloroacetic acid-precipitable.

Three-month-old male C57BL/6J mice received a bolus injection with $6.9 \mathrm{MBq}{ }^{125} \mathrm{I}-\mathrm{A} \beta$ in $0.3 \mathrm{ml}$ of lactate Ringer's solution $\left(6 \mathrm{~g} / \mathrm{L} \mathrm{NaCl}, 0.2 \mathrm{~g} / \mathrm{L} \mathrm{CaCl}_{2}, 3.1 \mathrm{~g} / \mathrm{L}\right.$ sodium lactate, $0.3 \mathrm{~g} / \mathrm{L} \mathrm{KCl}, \mathrm{pH} 7.1)$ via the tail vein $(n=8)$. Mice were sacrificed by overdose of ketamine at $120 \mathrm{~min}$ after injection. The brain, skin, gastrointestinal tract, lung, heart, liver, spleen, kidney, and carcass were collected and weighted. The radioactivity (CPM values) of samples was measured with a wipe test counter (CAPRAC), and the resulting counts/min was normalized per gram of tissue. The radioactivity values are shown as \% of total radioactivity or counts/min/gram of tissue.

\section{Parabiosis}

APPswe/PS1dE9 transgenic (Tg) mice were bred in the animal facility of Daping hospital. All mouse husbandry procedures were approved by the Third Military Medical University Animal Welfare Committee. To exclude the influence of gender on brain $\mathrm{A} \beta$ deposition, female $\mathrm{Tg}$ mice were used in the present study. Each pair of mice was placed together in a cage for 1 month to allow the mice to adapt to each other $[10,11]$. Female Tg mice and their age- and weight-matched female wild-type (Wt) littermates 

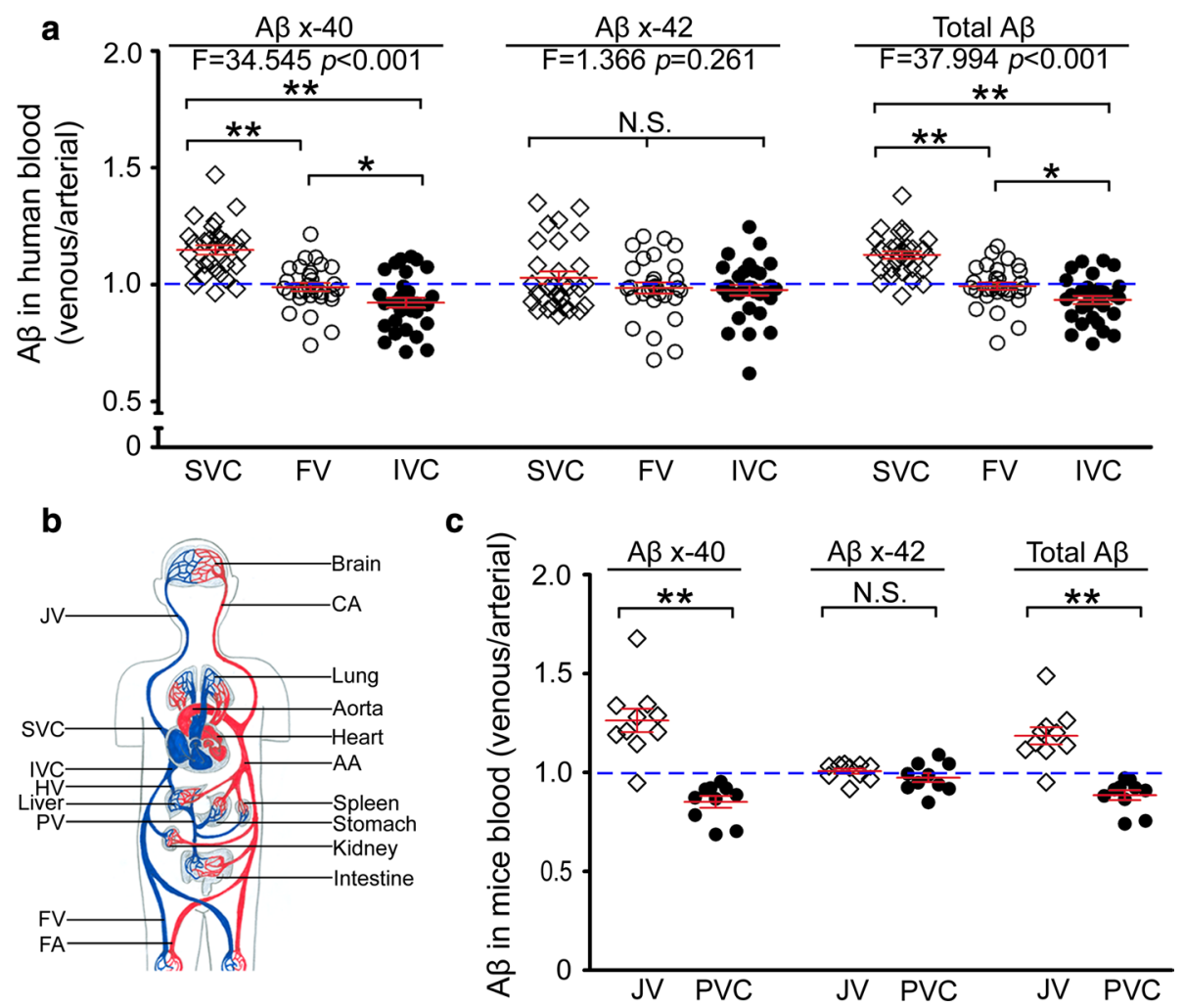

Fig. $1 \mathrm{~A} \beta$ concentrations at different locations of the systemic circulation. a The venous/arterial $(V / A)$ ratio of $\mathrm{A} \beta$ concentrations among blood samples from different venous locations in humans $(n=30)$. The blue dotted line represents $\mathrm{A} \beta$ concentration in the femoral artery $(F A)$ as a reference. $\mathbf{b}$ A diagram of the circulation system and sampling locations for $\mathrm{A} \beta$ measurement. The superior vena cava $(S V C)$ collects blood from the head containing brain-derived $A \beta$. The inferior vena cava $(I V C)$ proximal to the hepatic vein $(H V)$ collects blood from the lower part of the body including liver, kidney, and gastrointestinal tract. The femoral vein $(F V)$ contains metabolites after the circulation through the lower limbs. The femoral artery $(F A)$ contains blood virtually identical to that in the aorta and is used as a reference. c The venous/arterial (V/A) ratio of $\mathrm{A} \beta$ concentrations among blood samples from different locations in APPswe/PS1 mice $(n=10)$. The blue dotted line represents the $\mathrm{A} \beta$ concentration in abdominal aorta $(A A)$ as a reference. $C A$ carotid artery, $P V$ portal vein, $J V$ jugular vein, $S V C$ superior vena cava, $I V C$ inferior vena cava, $H V$ hepatic vein, $F V$ femoral vein, $F A$ femoral artery, $P V C$ posterior vena cava. Mean \pm SEM, one-way ANOVA and Tukey's test for human plasma and 2-tailed $t$ test for mouse plasma, ${ }^{*} P<0.05$, ${ }^{*} P<0.01$. N.S. no statistical significance

the surgery, the parabiotic mice were allowed to recover in a warm and clean environment before being transferred into the husbandry area. Prophylactic antibiotic treatment (enrofloxacin, $5 \mathrm{mg} / \mathrm{kg}$ ) was started 1 day prior to the surgery and continued for 1 week. All animals received analgesic/ anti-inflammatory treatment (acetylsalicylic acid $5 \mathrm{mg} / \mathrm{kg}$ ) for 2 weeks.

\section{Brain sampling}

Animals were euthanized by overdosing with pentobarbital $(0.08 \mathrm{~g} / \mathrm{kg})$. Blood was sampled from the right atrium of the heart, followed by intracardial perfusion with $100 \mathrm{ml}$ of $0.1 \% \mathrm{NaNO}_{2}$ in phosphate buffer. Brains were sampled and weighed. Left hemispheres were fixed in $4 \%$ paraformaldehyde for histological analysis, and right hemispheres were snap frozen in liquid nitrogen and stored at $-80{ }^{\circ} \mathrm{C}$ for biochemical analysis. 


\section{Histology and quantification}

Coronal sections of the brain were cut at a $35 \mu \mathrm{m}$ thickness with a cryosectioning microtome and stored at $4{ }^{\circ} \mathrm{C}$ in PBS containing $0.1 \%$ sodium azide until use. For the histology analysis, a series of five equally spaced tissue sections ( $\sim 1.3 \mathrm{~mm}$ apart) spanning the entire brain were used for each type of staining.

\section{A $\beta$ plaques}

The compact $\mathrm{A} \beta$ plaques were visualized with Congo red staining following our previous protocols [51]. In brief, sections were treated with working sodium chloride solution (containing sodium chloride saturated in $80 \%$ alcohol and $0.01 \%$ sodium hydroxide) at room temperature (RT) for $20 \mathrm{~min}$, then placed directly into working Congo red solution (containing saturated Congo red in working sodium solution) for $1 \mathrm{~h}$, and then dehydrated rapidly in absolute alcohol. The total $\mathrm{A} \beta$ plaques containing both compact and diffuse plaques were visualized with antibody 6E10 immunohistochemistry.

\section{Cerebral amyloid angiopathy (CAA)}

Cerebral amyloid angiography (CAA) were visualized with Congo red staining and quantified following previously described protocols [48]. In brief, sections were stained with Congo red and images were collected at the selected regions from frontal cortex to hippocampus of each mouse brain under the same illumination conditions. Quantification of Congo red staining was performed using the Image $\mathbf{J}$ software. A series of standard images representing extremes of high and low levels of Congo red staining were used to establish segmentation threshold using the RGB method to distinguish positively stained pixels. CAA was manually selected from each image, and the measurement of positively stained pixels was performed under the same RGB segmentation values. This yields the amyloid load due to Congo red staining of blood vessels. Meanwhile, the average number of CAA profiles per section was calculated by dividing the total count of CAA with the total number of sections as in our previous study [50].

\section{Microhemorrhage}

Sections were stained for hemosiderin with $2 \%$ potassium ferrocyanide in $2 \%$ hydrochloric acid for $15 \mathrm{~min}$, followed by a counterstaining with $1 \%$ Neutral Red solution for $10 \mathrm{~min}$ at room temperature [51]. Microhemorrhage profiles were counted under microscopy, and the average number of hemosiderin deposits per section was calculated.
Neuronal degeneration

Apoptosis of neuronal cells was detected with NeuN and Caspase-3 double immunofluorescence staining. Neuronal loss and neurite degeneration were detected with NeuN and microtubule-associated protein (MAP)-2 double immunofluorescence staining.

\section{Astrocytosis and microgliosis}

Immunohistochemistry was used to visualize astrocytosis and microgliosis with anti-CD45 antibody to detect activated microglia and anti-glial fibrillary acidic protein (GFAP) antibody to detect astrocytes.

Quantification was conducted by an investigator who was blinded to the group information of the samples. The area fraction and/or density of positive staining was quantified with ImageJ software.

\section{ELISA assays}

Frozen brain was homogenized in liquid nitrogen and successively extracted with TBS, $2 \%$ SDS, and $70 \%$ formic acid solutions following our previous protocols [51]. Levels of $A \beta 40$ and $A \beta 42$ were measured using ELISA kits (Covance). Concentrations of inflammatory cytokines IL-6, IL- $1 \beta$ and TNF- $\alpha$ in brain extracts and blood were quantitatively measured with ELISA according to the manufacturer's instructions (eBioscience).

\section{Western blotting}

The levels of molecules or enzymes involving $A \beta$ metabolism, phosphorylated Tau, and synapse-related proteins were analyzed using Western blotting. Proteins in the animal brain homogenate were extracted with RIPA buffer. Samples were loaded on SDS-PAGE (4-10\% acrylamide) gels. Separated proteins were transferred to nitrocellulose membranes. The blots were probed with the following antibodies: anti-APP C-Terminal (171610, Millipore) which recognizes full-length APP (APPfl) and C-terminal fragment (CTF)- $\beta$, anti-BACE1 (Millipore), anti-NEP (Millipore), anti-receptor for advanced glycosylation products (RAGE, Millipore), anti-LRP-1 (5A6, Calbiochem), anti-IDE (Epitomics), anti-phosphorylated-Tau antibodies including anti-pS396 (Signalway) and anti-pS199 (epitomics), anti-Synaptophysin (Millipore), anti-Synapsin-1 (Millipore), anti-PSD95 (Millipore), anti-PSD93 (Millipore) and anti- $\beta$-actin (Sigma-Aldrich). The membranes were incubated with IRDye $800 \mathrm{CW}$ secondary antibodies (LiCOR) and scanned using the Odyssey fluorescent scanner. The band density was normalized to $\beta$-actin for analysis. 


\section{Statistical analysis}

All data represent the mean \pm SEM. Statistical analysis included 2-tailed Student's $t$ test for the comparison of two groups, one-way ANOVA and Tukey's test for the comparison of multiple groups when required. Normality and equal-variance testing was performed for all assays. $P<0.05$ was considered significant. All analyses were completed with SPSS software, version 10.0.

\section{Results}

\section{$A \beta$ levels in different locations of the circulation}

A recent study in humans demonstrates the efflux of $\mathrm{A} \beta$ from the brain to the plasma [36]. However, the fate of brain-derived $A \beta$ in the periphery remains unclear. To examine the catabolism of brain-derived $A \beta$ in the periphery, we measured $A \beta$ levels in the different parts of the circulation including: (a) the superior vena cava which collects blood from the head containing brainderived $\mathrm{A} \beta$, (b) the inferior vena cava proximal to the hepatic vein which collects blood from the lower part of the body including liver, kidney and gastrointestinal tract, (c) the femoral vein which contains metabolites after the circulation through the lower limbs, and (d) the femoral artery which contains blood virtually identical to that in the aorta and used as a reference (Fig. 1b, Supplemental Table 1). In addition, $A \beta$ levels in blood from the jugular vein, the abdominal aorta and the posterior vena cava were examined in AD mice aged 6 months (Supplemental Table 2). The A $\beta$ concentrations in different locations of the circulation were divided by time-matched arterial $\mathrm{A} \beta$ concentrations to generate the venous/arterial (V/A) ratio. We found that V/A ratios of $\mathrm{A} \beta 40$ and total $\mathrm{A} \beta$ from the superior vena cava were significantly higher than that from the inferior vena cava in humans (Fig. 1a), and V/A ratios of $A \beta 40$ and total $\mathrm{A} \beta$ from the jugular vein of $\mathrm{AD}$ mice were also higher than that from the posterior vena cava (Fig. 1c). Interestingly, V/A ratios of $A \beta 40$ and total $A \beta$ from the inferior vena cava were significantly lower than that from the femoral vein in humans (Fig. 1a). These findings suggest that brain-derived $A \beta$ in the arterial blood is physiologically cleared when it goes through the capillary beds of the peripheral organs and tissues, and that the internal organs remove significant amounts of arterial $\mathrm{A} \beta$. There were no differences in $A \beta 42$ concentrations among different locations of the circulation in both humans and $\mathrm{AD}$ mice (Fig. 1a, c), suggesting that $\mathrm{A} \beta 42$ is not a sensitive marker to reflect peripheral $A \beta$ catabolism possibly due to its low level in blood [36].

\section{Distribution of ${ }^{125} \mathrm{I}-\mathrm{A} \beta 1-40$ in peripheral tissues and organs}

We next investigated where $A \beta$ is metabolized in the periphery in wild-type mice. Two hours after intravenous (i.v.) bolus injection of ${ }^{125} \mathrm{I}$ labeled $\mathrm{A} \beta$ through the tail vein different organs and tissues were collected and weighed. In addition, radioactivities were detected respectively following a previous protocol [8]. We found that the injected radioactivity was located mostly in the liver, kidney, gastrointestinal tract, and skin while the rest was located in the carcass (Supplemental Fig. 1a). Moreover, by normalizing the data according to the mouse weights, we also observed significant amounts of radioactivity uptake in the liver, kidney, gastrointestinal tract, and skin but little in the carcass (Supplemental Fig. 1b). The radioactivity uptake in the brain accounted for only $1.67 \%$ of total injected radioactivity, suggesting that peripheral organs and tissues are the main places of $A \beta$ clearance in the periphery. This is particularly true for the liver and kidney, which are suggested to be the major organs for uptake of exogenous $A \beta$ in the blood [8].

\section{Parabiosis reduces brain amyloid deposition}

The above findings raise a critical question of whether the clearance of $A \beta$ by the peripheral system has any impact on the pathogenesis of $\mathrm{AD}$. We utilized isochronic parabiosis to test the efficacy of peripheral clearance of $A \beta$ in alleviating the amyloid burden in the brains of APPswe/PS1dE9 transgenic mice. After parabiosis between transgenic and wildtype mice, the circulation of the parabionts was connected so that $A \beta$ species in the blood of the parabiotic transgenic mice could be transported into the wild-type mice. Thus, the transgenic mice acquired an additional peripheral system from wild-type mice. This model provided a reliable approach to test the $\mathrm{A} \beta$ clearing capacity of the peripheral system.

Parabiosis was performed before $A \beta$ deposition at 3 months of age and samples were collected for analysis after $A \beta$ deposition at 9 months of age (Supplemental Fig. 2a). After parabiosis, the blood levels of both $A \beta 40$ and $\mathrm{A} \beta 42$ of the parabiotic transgenic mice [pa(3-9mon) $\mathrm{Tg}$ ] were significantly lower than that of the control transgenic mice (Supplemental Fig. 2b). Additionally, blood A $\beta$ levels of the parabiotic wild-type mice [pa(3-9mon) Wt mice] were comparable to that of $\mathrm{pa}(3-9 \mathrm{mon}) \mathrm{Tg}$ mice. These findings suggest that $\mathrm{A} \beta$ from the pa(3-9mon)Tg mice entered the circulation of the pa(3-9mon)Wt mice.

Compared with control transgenic mice, pa(3-9mon)Tg mice had dramatic reductions in area fraction and plaque density of both compact plaques stained with Congo red, total plaques stained with $6 \mathrm{E} 10$ in neocortex and hippocampus (Fig. 2a-d), A $\beta$ deposition in vessel walls (CAA) 
(Fig. 2h-j), and microbleed profiles (Supplemental Fig. 3). The total area fraction of amyloid deposition in both hippocampus and neocortex was reduced by $70 \%$ for Congo red positive plaques, and $86 \%$ for $6 \mathrm{E} 10$ positive plaques in pa(3-9mon)Tg mice relative to control transgenic mice (Fig. 2b, d). After parabiosis, the levels of $A \beta 40$ and $A \beta 42$ were significantly reduced in the brain homogenates of $\mathrm{pa}(3-9 \mathrm{mon}) \mathrm{Tg}$ mice in comparison with control transgenic mice, with a reduction of total $\mathrm{A} \beta$ by $68 \%$ (Fig. $2 \mathrm{e}-\mathrm{g}$ ). These data suggest that providing an additional peripheral system by parabiosis can substantially prevent $\mathrm{A} \beta$ deposition in the brain of transgenic mice.

We further investigated whether enhancement of peripheral $A \beta$ clearing capacity could reduce $A \beta$ burden after extensive $A \beta$ deposition in the brain using the parabiosis models between 9-month-old female transgenic and agematched female wild-type mice. Similarly, after 3 month parabiosis, the Congo red and 6E10-positive $\mathrm{A} \beta$ plaque burdens in the neocortex in $\mathrm{pa}(9-12 \mathrm{mon}) \mathrm{Tg}$ mice were significantly lower than that of 12 months old transgenic control, and there was no significant increase in $A \beta$ plaque burdens in $\mathrm{pa}(9-12 \mathrm{mon}) \mathrm{Tg}$ mice when compared with 9-month-old transgenic mice (Supplemental Fig. 4). Taken together, our findings suggest that enhancing $\mathrm{A} \beta$ clearance in the periphery has both preventive and treatment potential for AD.

As the amyloid burden is associated with both $\mathrm{A} \beta$ production and clearance, we further investigated the metabolism of APP after parabiosis. There were no significant differences in the levels of full-length APP (APPfl), C-terminal fragment (CTF)- $\alpha$, CTF- $\beta$, beta-secretase (BACE)$1, A \beta$-degrading enzymes IDE and NEP, and $A \beta$ transport receptors across BBB (LRP-1 and RAGE) in the brain between the pa(3-9mon)Tg mice and the control transgenic mice (Supplemental Fig. 5), suggesting that the reduction of brain $\mathrm{A} \beta$ burden after parabiosis was not due to changes in $\mathrm{A} \beta$ production or degradation. In addition, as the parabiotic mice were of the same age, the reduced brain $\mathrm{A} \beta$ burden was not due to the rejuvenation mechanism as observed in a previous parabiosis study [42].

\section{Parabiosis attenuates AD-type pathologies}

We investigated whether other $\mathrm{AD}$ pathologies could also be attenuated in the brain after parabiosis. In comparison with control transgenic mice, inflammation was significantly attenuated in the brain of $\mathrm{pa}(3-9 \mathrm{mon}) \mathrm{Tg}$ mice, as reflected by decreased levels of astrocytosis and microgliosis (Fig. 3a-f), and reduced levels of proinflammatory cytokines including TNF- $\alpha$, IL-1, and IL-6 (Supplemental Fig. 6). The levels of phosphorylated Tau (pS199 and pS396), but not total Tau (Tau5), were significantly reduced in the brain of $\mathrm{pa}(3-9 \mathrm{mon}) \mathrm{Tg}$ mice after parabiosis (Fig. $3 g-j$ ).
Compared with control transgenic mice, the pa(3-9mon) $\mathrm{Tg}$ mice displayed less neuronal apoptosis and damage as reflected by caspase-3 staining in hippocampus (Fig. 4a-d), and higher levels of synapse-associated proteins including PSD93, PSD95, synapsin-1, and synaptophysin in the brain (Fig. 4e, f). These data suggest that neurodegeneration was attenuated in the brains of transgenic mice after parabiosis.

\section{Discussion}

In the present study, we provide evidence of physiological catabolism of brain-derived $A \beta$ in the peripheral system in humans and mice. Using this model of parabiosis we, for the first time, revealed that the physiological ability of $\mathrm{A} \beta$ clearance in the periphery has a significant impact on preventing $A \beta$ accumulation in the brain, as reflected by around $80 \%$ reduction of brain $\mathrm{A} \beta$ deposition after parabiosis. Liver, kidney, gastrointestinal tract and skin are the major places for $A \beta$ catabolism in the periphery. The other $\mathrm{AD}$-associated pathologies, including tau phosphorylation, neuroinflammation, and neuronal degeneration, were also significantly attenuated in the brains of $\mathrm{AD}$ mice after parabiosis.

We also found that peripheral clearance of brain-derived $\mathrm{A} \beta$ exists physiologically. A recent study revealed the efflux of brain-derived $A \beta$ to peripheral blood [36]. Consistently, we found that the blood $A \beta$ levels in the superior vena cava were higher than that in the femoral artery, suggesting that $\mathrm{A} \beta$ effluxes from the brain into peripheral blood. However, the previous study did not address the question of whether brain-derived $A \beta$ is catabolized in the peripheral system. This information is critical for understanding AD pathogenesis and development of approaches for prevention and treatment of AD. In the present study, we found that blood $\mathrm{A} \beta$ levels in the inferior vena cava were significantly lower than that in the femoral artery in human. This pattern of changes was confirmed in APPswe/PS1 mice whose blood $\mathrm{A} \beta$ levels in jugular vein were higher than that in abdominal aorta, and blood $A \beta$ levels in posterior vena cava were lower than that in abdominal aorta. These findings suggest that brain-derived $\mathrm{A} \beta$ in the arterial blood is physiologically cleared when it goes through the capillary bed of the peripheral organs and tissues, in particular, liver, kidney, gastrointestinal tract, and skin.

The parabiosis model was used to test the efficacy of natural peripheral $A \beta$ clearance in removing brain $A \beta$ in AD mice. After parabiosis, the circulations of the parabiotic mice were connected, and thus $\mathrm{A} \beta$ species in the blood of the parabiotic $\mathrm{AD}$ mice could be transported to the wildtype mice for clearance. Parabiosis provides parabiotic AD mice an additional set of peripheral tissues and organs from wild-type mice. As such it is a reliable model to test 


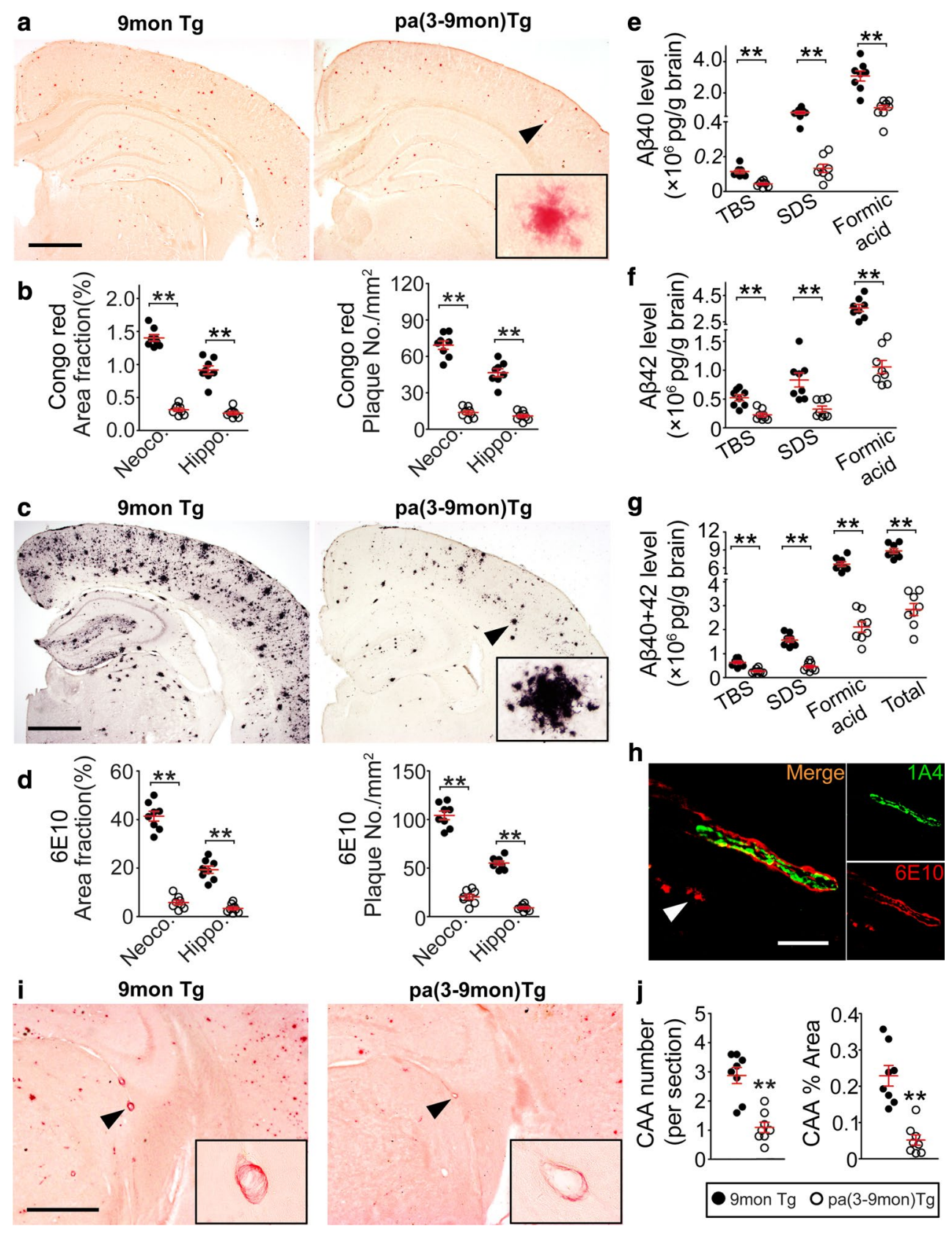

Fig. 2 Parabiosis reduces brain amyloid burden of AD mice. a, c Representative images of Congo red and 6E10 immunohistochemical staining in neocortex and hippocampus in 9 mon $\mathrm{Tg}$ and pa(3-9mon) $\mathrm{Tg}$ mice. Insets show the representative morphology at higher magnification. Scale bars $500 \mu \mathrm{m}$. b, d Comparison of the area fraction and density of Congo red or $6 \mathrm{E} 10$-positive $\mathrm{A} \beta$ plaques in the neocortex (Neoco.) and hippocampus (Hippo.) between 9mon Tg and pa(39mon) $\mathrm{Tg}$ mice. e, f, $\mathbf{g}$ Comparison of $\mathrm{A} \beta 40, \mathrm{~A} \beta 42$ and total $\mathrm{A} \beta$ levels measured with ELISA in TBS, $2 \%$ SDS and $70 \%$ formic acid fractions of brain extracts between $9 \mathrm{mon} \mathrm{Tg}$ and $\mathrm{pa}(3-9 \mathrm{mon}) \mathrm{Tg}$ mice.

the efficacy of peripheral $A \beta$ clearance. After parabiosis, brain $\mathrm{A} \beta$ plaques of $\mathrm{AD}$ mice were dramatically reduced by around $80 \%$. It is unlikely that changes in $\mathrm{A} \beta$ production, degradation, or transport across BBB play dominant h Illustration of Cerebral amyloid angiopathy $(C A A)$ by immunofluorescence with the antibody to $\mathrm{A} \beta(6 E 10)$ and smooth muscle in the vessel wall (1A4). The arrow indicates the $\mathrm{A} \beta$ plaques in the brain parenchyma near the CAA. Scale bars $100 \mu \mathrm{m}$. i CAA visualized using Congo red staining. Insets show the representative morphology of CAA stained by Congo red at higher magnification. Scale bars $500 \mu \mathrm{m}$. $\mathbf{j}$ Comparison of numbers of CAA profiles and area fraction of CAA between 9 mon Tg and pa(3-9mon) Tg mice. $n=8$ per group, mean \pm SEM, 2-tailed $t$ test, $* P<0.05, * * P<0.01$

roles in the reduction of brain $A \beta$ of the parabiotic $A D$ mice, as there were no significant changes in the expression of APPfl, CTF- $\alpha$, CTF- $\beta$, BACE1, IDE, NEP, LRP-1, and RAGE. A recent study shows that parabiosis between 

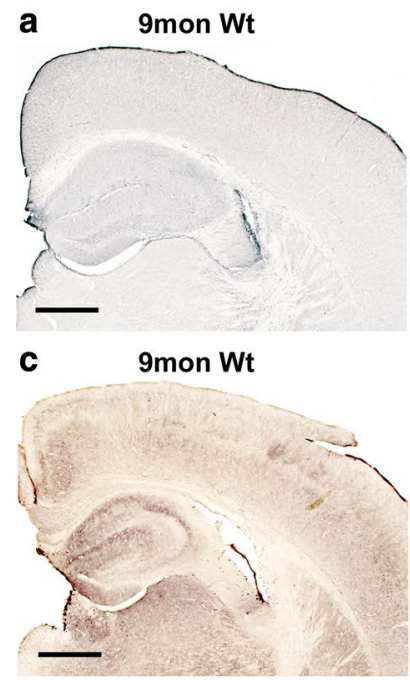

e

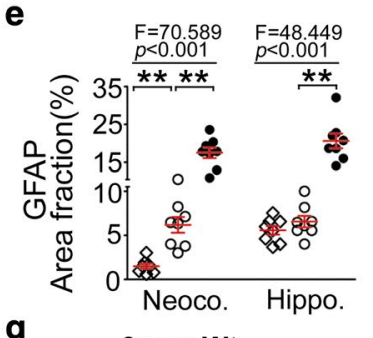

g
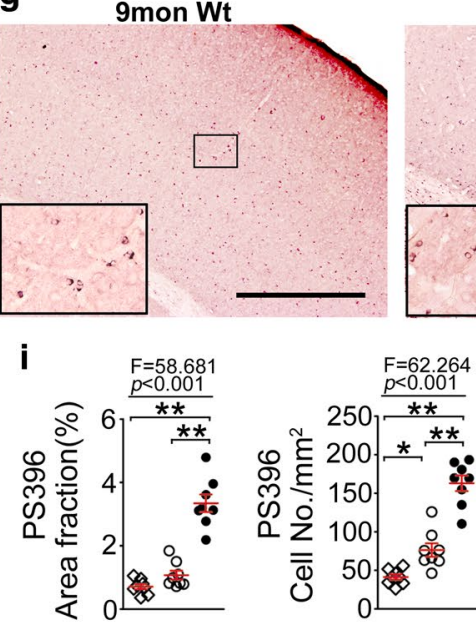

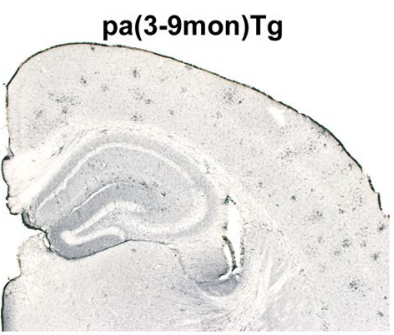

$\mathrm{pa}(3-9 \mathrm{mon}) \mathrm{Tg}$
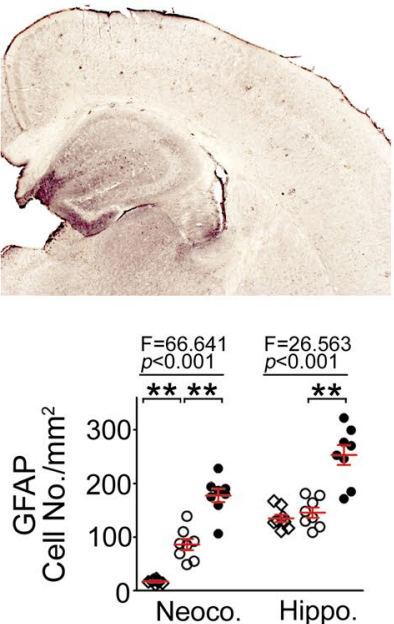

pa(3-9mon)Tg
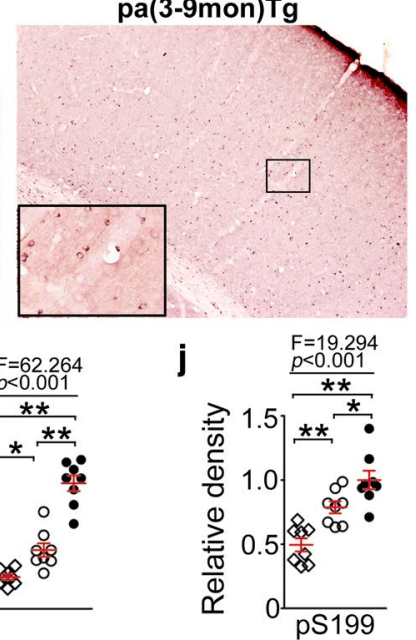

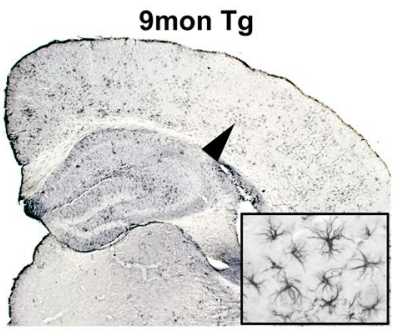

9mon Tg

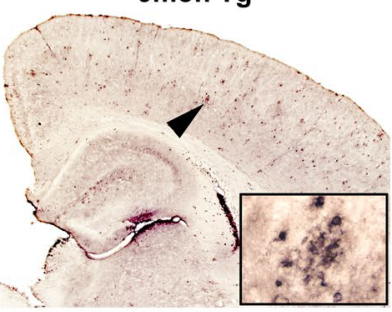

f
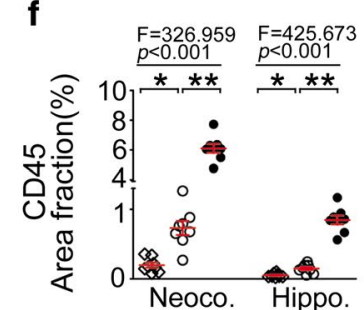

9mon Tg

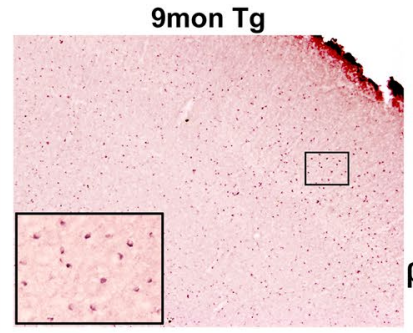

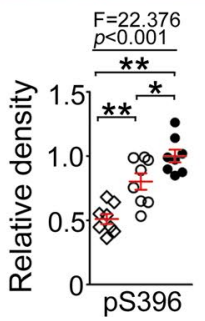

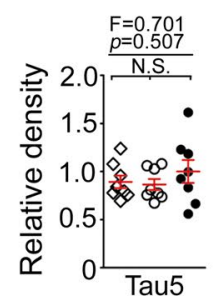

b

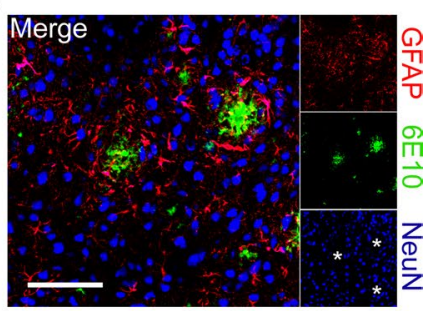

d
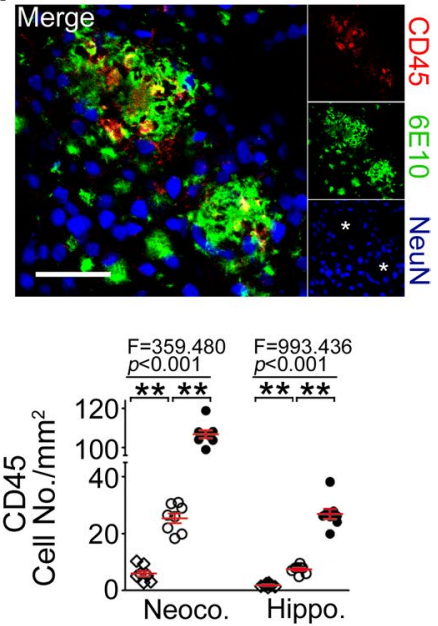

h

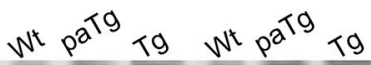

pS199

pS396

Tau5

B-Actin

Fig. 3 Parabiosis attenuates neuroinflammation and Tau phosphorylation. a Representative images of astrocytosis stained with anti-GFAP antibody in the brain. Insets show the representative morphology at higher magnification. Scale bars $500 \mu \mathrm{m}$. b Immunofluorescence image of amyloid deposition and astrocytosis co-stained with 6E10 (green) and anti-GFAP (red) antibodies. A $\beta$ plaques were surrounded by activated astrocytes. Scale bars $100 \mu \mathrm{m}$. c Representative images of microgliosis stained with anti-CD45 antibody in the brain. Insets show the representative morphology at higher magnification. Scale bars $500 \mu \mathrm{m}$. d Immunofluorescence image of amyloid deposition and microgliosis co-stained with $6 \mathrm{E} 10$ and anti-CD45 antibodies. A $\beta$ plaques were surrounded by activated microglia. Scale bars $50 \mu \mathrm{m}$. e, $\mathbf{f}$ Comparisons of area fraction and cell density of astrocytosis (e) and microgliosis (f) in the neocortex (Neoco.) and hippocampus (Hippo.) among pa(3-9mon)Tg mice, control Tg mice and Wt mice. g Repre-

sentative images of intracellular Tau phosphorylation stained with anti-pSer396 antibody in the brain. Insets show the representative morphology at higher magnification. Scale bars $500 \mu \mathrm{m}$. h Western blot assays of phosphorylated Tau at multiple sites including pSer199, pSer396, and total Tau (Tau5) in the brain homogenates of parabiotic $\mathrm{Tg}$ mice $(\mathrm{PaTg})$, control Tg mice and wild-type mice $(W t)$. i Comparisons of area fraction and cell density of cells containing phosphorylated Tau stained with anti-pSer396 antibody in the neocortex among parabiotic $\mathrm{Tg}$ mice $(\mathrm{PaTg})$, control $\mathrm{Tg}$ mice and wild-type mice. j Comparison of band density for phosphorylated Tau (pS199 and $p$ S396) and total Tau (Tau5) shown in $\mathbf{h}$ among pa(3-9mon)Tg mice, control Tg mice and Wt mice. $n=8$ per group, mean \pm SEM., one-way ANOVA and Tukey's test, ${ }^{*} P<0.05, * * P<0.01$. N.S. no statistical significance 
Fig. 4 Parabiosis alleviates neuronal degeneration and loss in the hippocampus of pa(3-9mon)Tg mice. a Representative images of neurons and dendrites at CA1 region of hippocampus stained with anti-NeuN and anti-MAP-2 immunofluorescence in pa(39mon)Tg mice, control Tg mice, and wild-type $(W t)$ mice. Scale bars $100 \mu \mathrm{m}$. b Comparison of the area fractions of NeuN and MAP-2 staining among pa(3-9mon)Tg mice, control Tg mice, and Wt mice. c Comparison of area fractions of caspase-3 staining among pa(39mon)Tg mice, control Tg mice, and Wt mice. $\mathbf{d}$ Representative images of neuronal apoptosis at CA3 region of hippocampus as stained with activated caspase-3 immunofluorescence. Scale bars $100 \mu \mathrm{m}$. e Western blot assays of synapse-associated proteins including PSD93, PSD95, synapsin1 (SYN-1), and synaptophysin (Synap.) in brain homogenates of $\mathrm{pa}(3-$ 9mon)Tg mice, control Tg mice, and wild-type $(W t)$ mice. f Comparisons of band density of PSD93, PSD95, SYN-1, and Synap. among pa(3-9mon) $\mathrm{Tg}$ mice, control Tg mice, and wild-type mice. $n=8$ per group, mean \pm SEM, one-way ANOVA and Tukey's test, $* P<0.05, * * P<0.01$
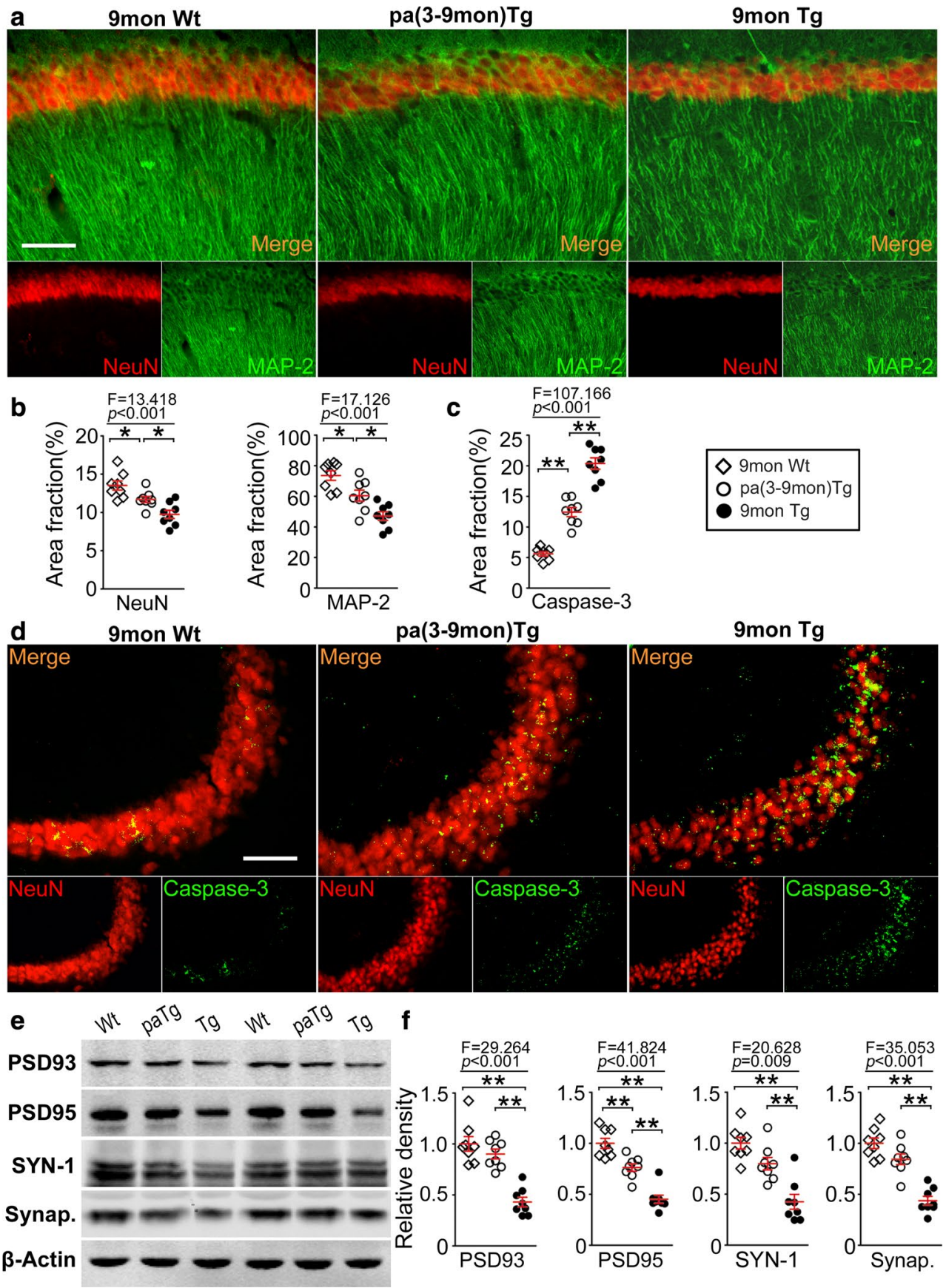

APPswe/PS1 mouse with ApoE gene and APPswe/PS1 mouse without ApoE gene did not reduce compact plaque burden in the brain of APPswe/PS1 mice with the ApoE gene [31]; suggesting that the systematic inflammation or immune responses induced by the parabiosis surgery would not be responsible for the large reduction of brain $\mathrm{A} \beta$ burden observed in the present study. In addition, both acute and chronic systematic inflammation are suggested to accelerate but not halt $\mathrm{A} \beta$ deposition and disease progress of $\mathrm{AD}[13,14,19]$. Moreover, we found that human $\mathrm{A} \beta$ generated from the parabiotic $\mathrm{AD}$ mice can be detected in the blood of the parabiotic wild-type mice, indicating that $\mathrm{A} \beta$ from the $\mathrm{AD}$ mice entered the circulation of the parabiotic wild-type mice. These findings suggest that parabiosis reduces brain $A \beta$ burden through the clearance by peripheral tissues and organs, rather than through modulation of brain $A \beta$ production, degradation, receptor-mediated transport across the BBB, or systematic inflammation induced by the surgery.

The present study reveals the importance of natural $\mathrm{A} \beta$ catabolic capacity of the peripheral system in clearing brain $\mathrm{A} \beta$. Based on the above findings, we can calculate 
the percentage of brain $A \beta$ clearance by a singular peripheral system. We define the brain $A \beta$ burden of an $A D$ mouse as $100 \%$ and the reduction of brain $\mathrm{A} \beta$ by adding an additional peripheral system as $68 \%$ of the brain $A \beta$ burden of the AD mice as indicated in our study. Accordingly, the total $\mathrm{A} \beta$ in the brain of the $\mathrm{AD}$ mice should be $100 \%+100 \% \times 68 \%$. Thus, a singular peripheral system can remove $40.4 \%$ of $A \beta$ burden in the brain as derived from the equation: clearance rate of a singular peripheral system $=\%$ reduction of brain $\mathrm{A} \beta$ in parabiotic $\mathrm{AD}$ mice/ $[100 \%+\%$ reduction of brain $\mathrm{A} \beta$ in parabiotic $\mathrm{AD}$ mice]. This calculation is close to the estimation that efflux of $A \beta$ to peripheral blood accounts for $50 \%$ of total brain $A \beta$ clearance in humans [36], suggesting that the physiological $\mathrm{A} \beta$ clearance capacity of the peripheral system provides an important mechanism against $A \beta$ accumulation in the brain.

Our findings also imply that dysfunction of peripheral $A \beta$ clearance may contribute to the development of AD. Indeed, a previous study showed that moderate renal impairment is associated with the increased risk for developing dementia [38]. We also found that the levels of $A \beta$ in blood are higher in patients with renal failure than normal controls [26]. Recent studies reveal that an allele $\left(\mathrm{rs} 3865444^{\mathrm{C}}\right)$ of $\mathrm{CD} 33$, which attenuates the $\mathrm{A} \beta$ internalization capacity of monocytes, is associated with the increased risk of $\mathrm{AD}[2,30]$. These findings support the notion that peripheral $A \beta$ metabolism is involved in $\mathrm{AD}$ pathogenesis.

Clearance of brain $A \beta$ represents a promising anti-A $\beta$ therapeutic strategy. Peripheral $A \beta$ clearance is proposed to be a safer therapeutic approach for $\mathrm{AD}[25,45]$ as adverse effects, such as neuroinflammation, vasogenic edema, and microhemorrhage occurred in trials of immunotherapies which target $\mathrm{A} \beta$ clearance likely due to the entry of anti-A $\beta$ antibodies into the brain and cerebral vessel walls (see review in [24]). Recently, we found that an antibody against $\mathrm{N}$-terminus of $\mathrm{A} \beta$ can facilitate the conversion of $\mathrm{A} \beta$ fibrils into more toxic $\mathrm{A} \beta$ oligomers, and then induce neuronal death in the brain [23]. This might be a reason for the acceleration of brain atrophy after clearance of $A \beta$ by antibodies in the AN1792 trials [7]. In addition, the antibody against $\mathrm{N}$-terminus of $\mathrm{A} \beta$ can cross bind to APP on the surface of neurons and promote the generation of $A \beta[5$, 20], and binding of autoantibodies to neurons is associated with increased level of intracellular $A \beta$ [29]; suggesting that antibodies against $A \beta$ or neuronal surface APP molecule may also increase $A \beta$ production once they enter the brain. Taken together, these findings suggest that removal of brain $\mathrm{A} \beta$ from a peripheral approach might be a safe therapeutic way for AD.

Some efforts were made by previous investigations to test the therapeutic efficacy of peripheral $A \beta$ clearance for $\mathrm{AD}$. Enhancement of $\mathrm{A} \beta$ degradation in liver by Withania somnifera extracts significantly reduced $\mathrm{A} \beta$ levels in the brain [37]. Peripheral administration of a single chain antibody ( $\mathrm{scFv}$ ) to $\mathrm{A} \beta$ is as effective as intracranial administration of the $\mathrm{scFv}$ in reducing brain $\mathrm{A} \beta$ burden, but does not increase brain levels of soluble $\mathrm{A} \beta$, which has potential to form more toxic oligomeric species [46]. However, intravenous infusion of antibody solanezumab as a peripheral "sink" inducer failed to remove brain $A \beta$ deposits [6]. Also, peripheral administration of NEP reduces blood $A \beta$ levels but fails to clear $A \beta$ accumulated in the brain $[12,44]$. In contrast, other studies indicate that continuous peripheral expression of NEP gene in skeletal muscle is able to reduce brain $\mathrm{A} \beta$ burden $[9,21,22]$. A critical reason for these conflicting results is that these $A \beta$ clearing agents may also enter the brain, directly interact with $\mathrm{A} \beta$, and even prohibit brain $\mathrm{A} \beta$ clearance under certain circumstances. For example, a monoclonal antibody 266 , the parental antibody of solanezumab, can enter the brain and form the complex with soluble $A \beta$ species; thus, retarding the efflux of $A \beta$ from the brain into the blood [49]. In addition, NEP also catabolizes a variety of substrates other than $A \beta$; some of which (i.e. bradykinin, atrial natriuretic factor) are involved in brain $A \beta$ accumulation or transport across $\mathrm{BBB}[16,33]$. Thus, these studies did not take a pure approach of clearing $A \beta$ in the periphery. In this regard, reliable methodologies are needed to test the efficacy of peripheral $A \beta$ clearance. Herein, by using a model of parabiosis to provide AD mice with an additional peripheral system, we provide a clear answer to the controversial issue that peripheral clearance of $A \beta$ is a valid therapeutic approach for $A D$. Although the parabiosis cannot be applied to human for AD therapy, enhancement of $A \beta$ catabolism in the periphery such as liver, kidney, or gastrointestinal tract would be a potential valid approach for developing AD therapy in the future.

The property of a therapeutic agent being able to penetrate the BBB is generally regarded as a prerequisite for anti-AD agents. Based on our findings drugs which directly act on $A \beta$ in the periphery would have a therapeutic significance even though they do not pass through BBB. Indeed, a parabiosis study shows that circulating ApoE, which does not enter the brain, acts as a peripheral sink to induce net efflux of $A \beta$ from the brain [31]. Thus, drug development against $A \beta$ in the future can focus on the clearance of $A \beta$ from the circulation and might be a promising therapeutic approach for AD.

Like other studies using the model of parabiosis [1, 4, 43], we did not perform behavioral tests to examine whether cognition is improved after parabiosis, as separation of the parabionts causes substantial lesions and stress to the animals. But consistent with the reduction in brain $\mathrm{A} \beta$ burden parabiosis also alleviated the other AD pathologies including tau phosphorylation, neuroinflammation, and neurodegeneration. This suggests that $\mathrm{A} \beta$ catabolism in the periphery is able to generate therapeutic efficacy. 
In conclusion, our study reveals the substantial contribution of the peripheral system to the clearance of brain $\mathrm{A} \beta$, providing proof-of-concept evidence that development of drugs and therapies for $\mathrm{AD}$ could be focused on peripheral rather than central $\mathrm{A} \beta$ clearance [25]. This study also implies that deficits in the $A \beta$ clearance of the peripheral system might also contribute to $\mathrm{AD}$ pathogenesis.

Acknowledgments This work was supported by the National Natural Science Foundation of China (Grant No. 81471296, 81270423). All procedures performed in studies involving human participants were in accordance with the ethical standards of the institutional and/or national research committee and with the 1964 Helsinki declaration and its later amendments or comparable ethical standards. All applicable international, national, and/or institutional guidelines for the care and use of animals were followed. The authors would like to thank the following for obtaining blood samples from patients: Dr. Maoqin Shu from Department of Cardiology, Southwest hospital of Third Military Medical University, Drs. Yuxiang Fang and Chunyu Zeng from Department of Cardiology, Daping hospital of Third Military Medical University, and Dr. Jun Jin from Department of Cardiology, Xinqiao hospital of Third Military Medical University.

\section{Compliance with ethical standards}

Conflict of interest The authors have declared that no conflict of interest exists.

Open Access This article is distributed under the terms of the Creative Commons Attribution 4.0 International License (http://creativecommons.org/licenses/by/4.0/), which permits unrestricted use, distribution, and reproduction in any medium, provided you give appropriate credit to the original author(s) and the source, provide a link to the Creative Commons license, and indicate if changes were made.

\section{References}

1. Ajami B, Bennett JL, Krieger C, Tetzlaff W, Rossi FM (2007) Local self-renewal can sustain CNS microglia maintenance and function throughout adult life. Nat Neurosci 10:1538-1543. doi:10.1038/nn2014

2. Bradshaw EM, Chibnik LB, Keenan BT, Ottoboni L, Raj T, Tang A, Rosenkrantz LL, Imboywa S, Lee M, Von Korff A, Alzheimer Disease Neuroimaging I, Morris MC, Evans DA, Johnson K, Sperling RA, Schneider JA, Bennett DA, De Jager PL (2013) CD33 Alzheimer's disease locus: altered monocyte function and amyloid biology. Nat Neurosci 16:848-850. doi:10.1038/ nn. 3435

3. Bu XL, Yao XQ, Jiao SS, Zeng F, Liu YH, Xiang Y, Liang CR, Wang QH, Wang X, Cao HY, Yi X, Deng B, Liu CH, Xu J, Zhang LL, Gao CY, Xu ZQ, Zhang M, Wang L, Tan XL, Xu X, Zhou HD, Wang YJ (2014) A study on the association between infectious burden and Alzheimer's disease. Eur J Neurol. doi:10.1111/ ene. 12477

4. Conboy IM, Conboy MJ, Wagers AJ, Girma ER, Weissman IL, Rando TA (2005) Rejuvenation of aged progenitor cells by exposure to a young systemic environment. Nature 433:760-764. doi:10.1038/nature03260
5. Deng J, Hou H, Giunta B, Mori T, Wang YJ, Fernandez F, Weggen S, Araki W, Obregon D, Tan J (2012) AutoreactiveAbeta antibodies promote APP beta-secretase processing. J Neurochem 120:732-740. doi:10.1111/j.1471-4159.2011.07629.x

6. Doody RS, Thomas RG, Farlow M, Iwatsubo T, Vellas B, Joffe S, Kieburtz K, Raman R, Sun X, Aisen PS, Siemers E, LiuSeifert H, Mohs R, Alzheimer's Disease Cooperative Study Steering C, Solanezumab Study G (2014) Phase 3 trials of solanezumab for mild-to-moderate Alzheimer's disease. N Engl J Med 370:311-321. doi:10.1056/NEJMoa1312889

7. Fox NC, Black RS, Gilman S, Rossor MN, Griffith SG, Jenkins L, Koller M (2005) Effects of Abeta immunization (AN1792) on MRI measures of cerebral volume in Alzheimer disease. Neurology 64:1563-1572

8. Ghiso J, Shayo M, Calero M, Ng D, Tomidokoro Y, Gandy S, Rostagno A, Frangione B (2004) Systemic catabolism of Alzheimer's Abeta40 and Abeta42. J Biol Chem 279:45897-45908. doi:10.1074/jbc.M407668200

9. Guan H, Liu Y, Daily A, Police S, Kim MH, Oddo S, LaFerla FM, Pauly JR, Murphy MP, Hersh LB (2009) Peripherally expressed neprilysin reduces brain amyloid burden: a novel approach for treating Alzheimer's disease. J Neurosci Res 87:1462-1473. doi:10.1002/jnr.21944

10. Harris RB (1999) Parabiosis between $\mathrm{db} / \mathrm{db}$ and ob/ob or $\mathrm{db} /+$ mice. Endocrinology 140:138-145. doi:10.1210/ endo.140.1.6449

11. Harris RB, Martin RJ (1984) Specific depletion of body fat in parabiotic partners of tube-fed obese rats. Am J Physiol 247:R380-R386

12. Henderson SJ, Andersson C, Narwal R, Janson J, Goldschmidt TJ, Appelkvist P, Bogstedt A, Steffen AC, Haupts U, Tebbe J, Freskgard PO, Jermutus L, Burrell M, Fowler SB, Webster CI (2014) Sustained peripheral depletion of amyloid-beta with a novel form of neprilysin does not affect central levels of amyloid-beta. Brain 137:553-564. doi:10.1093/brain/awt308

13. Heneka MT, Carson MJ, El Khoury J, Landreth GE, Brosseron F, Feinstein DL, Jacobs AH, Wyss-Coray T, Vitorica J, Ransohoff RM, Herrup K, Frautschy SA, Finsen B, Brown GC, Verkhratsky A, Yamanaka K, Koistinaho J, Latz E, Halle A, Petzold GC, Town T, Morgan D, Shinohara ML, Perry VH, Holmes C, Bazan NG, Brooks DJ, Hunot S, Joseph B, Deigendesch N, Garaschuk O, Boddeke E, Dinarello CA, Breitner JC, Cole GM, Golenbock DT, Kummer MP (2015) Neuroinflammation in Alzheimer's disease. Lancet Neurol 14:388-405. doi:10.1016/ S1474-4422(15)70016-5

14. Holmes C, Cunningham C, Zotova E, Woolford J, Dean C, Kerr S, Culliford D, Perry VH (2009) Systemic inflammation and disease progression in Alzheimer disease. Neurology 73:768-774. doi:10.1212/WNL.0b013e3181b6bb95

15. Iliff JJ, Wang M, Liao Y, Plogg BA, Peng W, Gundersen GA, Benveniste H, Vates GE, Deane R, Goldman SA, Nagelhus EA, Nedergaard M (2012) A paravascular pathway facilitates CSF flow through the brain parenchyma and the clearance of interstitial solutes, including amyloid beta. Science translational medicine 4:147ra111. doi:10.1126/scitranslmed.3003748

16. Ito S, Ohtsuki S, Murata S, Katsukura Y, Suzuki H, Funaki M, Tachikawa M, Terasaki T (2014) Involvement of insulin-degrading enzyme in insulin- and atrial natriuretic peptide-sensitive internalization of amyloid-beta peptide in mouse brain capillary endothelial cells. J Alzheimer's Dis: JAD 38:185-200. doi:10.3233/JAD-122077

17. Jankowsky JL, Fadale DJ, Anderson J, Xu GM, Gonzales V, Jenkins NA, Copeland NG, Lee MK, Younkin LH, Wagner SL, Younkin SG, Borchelt DR (2004) Mutant presenilins specifically elevate the levels of the 42 residue beta-amyloid peptide in vivo: 
evidence for augmentation of a 42-specific gamma secretase. Hum Mol Genet 13:159-170. doi:10.1093/hmg/ddh019

18. Jankowsky JL, Slunt HH, Ratovitski T, Jenkins NA, Copeland NG, Borchelt DR (2001) Co-expression of multiple transgenes in mouse CNS: a comparison of strategies. Biomol Eng $17: 157-165$

19. Kyrkanides S, Tallents RH, Miller JN, Olschowka ME, Johnson R, Yang M, Olschowka JA, Brouxhon SM, O'Banion MK (2011) Osteoarthritis accelerates and exacerbates Alzheimer's disease pathology in mice. J Neuroinflammation 8:112. doi:10.1186/1742-2094-8-112

20. Li S, Deng J, Hou H, Tian J, Giunta B, Wang Y, Sawmiller D, Smith A, Sanberg PR, Obregon D, Mori T, Tan J (2014) Specific antibody binding to the APP672-699 region shifts APP processing from alpha- to beta-cleavage. Cell Death Dis 5:e1374. doi:10.1038/cddis.2014.336

21. Liu Y, Studzinski C, Beckett T, Guan H, Hersh MA, Murphy MP, Klein R, Hersh LB (2009) Expression of neprilysin in skeletal muscle reduces amyloid burden in a transgenic mouse model of Alzheimer disease. Mol Ther 17:1381-1386. doi:10.1038/ mt.2009.115

22. Liu Y, Studzinski C, Beckett T, Murphy MP, Klein RL, Hersh LB (2010) Circulating neprilysin clears brain amyloid. Mol Cell Neurosci 45:101-107. doi:10.1016/j.mcn.2010.05.014

23. Liu YH, Bu XL, Liang CR, Wang YR, Zhang T, Jiao SS, Zeng F, Yao XQ, Zhou HD, Deng J, Wang YJ (2015) An N-terminal antibody promotes the transformation of amyloid fibrils into oligomers and enhances the neurotoxicity of amyloid-beta: the dust-raising effect. J Neuroinflammation. doi:10.1186/ s12974-015-0379-4

24. Liu YH, Giunta B, Zhou HD, Tan J, Wang YJ (2012) Immunotherapy for Alzheimer disease: the challenge of adverse effects. Nat Rev Neurol 8:465-469. doi:10.1038/nrneurol.2012.118

25. Liu YH, Wang YR, Xiang Y, Zhou HD, Giunta B, Manucat-Tan NB, Tan J, Zhou XF, Wang YJ (2015) Clearance of amyloid-beta in Alzheimer's disease: shifting the action site from center to periphery. Mol Neurobiol 51:1-7. doi:10.1007/ s12035-014-8694-9

26. Liu YH, Xiang Y, Wang YR, Jiao SS, Wang QH, Bu XL, Zhu C, Yao XQ, Giunta B, Tan J, Zhou HD, Wang YJ (2015) Association between serum amyloid-beta and renal functions: implications for roles of kidney in amyloid-beta clearance. Mol Neurobiol 52:115-119. doi:10.1007/s12035-014-8854-y

27. Louveau A, Smirnov I, Keyes TJ, Eccles JD, Rouhani SJ, Peske JD, Derecki NC, Castle D, Mandell JW, Lee KS, Harris TH, Kipnis J (2015) Structural and functional features of central nervous system lymphatic vessels. Nature 523:337-341. doi:10.1038/ nature 14432

28. Maness LM, Banks WA, Podlisny MB, Selkoe DJ, Kastin AJ (1994) Passage of human amyloid beta-protein 1-40 across the murine blood-brain barrier. Life Sci 55:1643-1650

29. Nagele RG, Clifford PM, Siu G, Levin EC, Acharya NK, Han M, Kosciuk MC, Venkataraman V, Zavareh S, Zarrabi S, Kinsler K, Thaker NG, Nagele EP, Dash J, Wang HY, Levitas A (2011) Brain-reactive autoantibodies prevalent in human sera increase intraneuronal amyloid-beta(1-42) deposition. J Alzheimers Dis 25:605-622. doi:10.3233/JAD-2011-110098

30. Naj AC, Jun G, Beecham GW, Wang LS, Vardarajan BN, Buros J, Gallins PJ, Buxbaum JD, Jarvik GP, Crane PK, Larson EB, Bird TD, Boeve BF, Graff-Radford NR, De Jager PL, Evans D, Schneider JA, Carrasquillo MM, Ertekin-Taner N, Younkin SG, Cruchaga C, Kauwe JS, Nowotny P, Kramer P, Hardy J, Huentelman MJ, Myers AJ, Barmada MM, Demirci FY, Baldwin CT, Green RC, Rogaeva E, St George-Hyslop P, Arnold SE, Barber R, Beach T, Bigio EH, Bowen JD, Boxer A, Burke JR, Cairns NJ, Carlson CS, Carney RM, Carroll SL, Chui HC, Clark DG,
Corneveaux J, Cotman CW, Cummings JL, DeCarli C, DeKosky ST, Diaz-Arrastia R, Dick M, Dickson DW, Ellis WG, Faber KM, Fallon KB, Farlow MR, Ferris S, Frosch MP, Galasko DR, Ganguli M, Gearing M, Geschwind DH, Ghetti B, Gilbert JR, Gilman S, Giordani B, Glass JD, Growdon JH, Hamilton RL, Harrell LE, Head E, Honig LS, Hulette CM, Hyman BT, Jicha GA, Jin LW, Johnson N, Karlawish J, Karydas A, Kaye JA, Kim R, Koo EH, Kowall NW, Lah JJ, Levey AI, Lieberman AP, Lopez OL, Mack WJ, Marson DC, Martiniuk F, Mash DC, Masliah E, McCormick WC, McCurry SM, McDavid AN, McKee AC, Mesulam M, Miller BL, Miller CA, Miller JW, Parisi JE, Perl DP, Peskind E, Petersen RC, Poon WW, Quinn JF, Rajbhandary RA, Raskind M, Reisberg B, Ringman JM, Roberson ED, Rosenberg RN, Sano M, Schneider LS, Seeley W, Shelanski ML, Slifer MA, Smith CD, Sonnen JA, Spina S, Stern RA, Tanzi RE, Trojanowski JQ, Troncoso JC, Van Deerlin VM, Vinters HV, Vonsattel JP, Weintraub S, Welsh-Bohmer KA, Williamson J, Woltjer RL, Cantwell LB, Dombroski BA, Beekly D, Lunetta KL, Martin ER, Kamboh MI, Saykin AJ, Reiman EM, Bennett DA, Morris JC, Montine TJ, Goate AM, Blacker D, Tsuang DW, Hakonarson H, Kukull WA, Foroud TM, Haines JL, Mayeux R, Pericak-Vance MA, Farrer LA, Schellenberg GD (2011) Common variants at MS4A4/MS4A6E, CD2AP, CD33 and EPHA1 are associated with late-onset Alzheimer's disease. Nat Genet 43:436-441. doi:10.1038/ng.801

31. Nilsson LN, Gografe S, Costa DA, Hughes T, Dressler D, Potter $\mathrm{H}$ (2012) Use of fused circulations to investigate the role of apolipoprotein $\mathrm{E}$ as amyloid catalyst and peripheral sink in Alzheimer's disease. Technol Innov 14:199-208. doi:10.3727/19498 2412X13462021398010

32. Pascale CL, Miller MC, Chiu C, Boylan M, Caralopoulos IN, Gonzalez L, Johanson CE, Silverberg GD (2011) Amyloid-beta transporter expression at the blood-CSF barrier is age-dependent. Fluids Barriers CNS 8:21. doi:10.1186/2045-8118-8-21

33. Passos GF, Medeiros R, Cheng D, Vasilevko V, Laferla FM, Cribbs DH (2013) The bradykinin B1 receptor regulates Abeta deposition and neuroinflammation in Tg-SwDI mice. Am $\mathbf{J}$ Pathol 182:1740-1749. doi:10.1016/j.ajpath.2013.01.021

34. Picken MM (2001) The changing concepts of amyloid. Arch Pathol Lab Med 125:38-43. doi:10.1043/0003-9985(2001)125<0038:TCCOA>2.0.CO;2

35. Preston SD, Steart PV, Wilkinson A, Nicoll JA, Weller RO (2003) Capillary and arterial cerebral amyloid angiopathy in Alzheimer's disease: defining the perivascular route for the elimination of amyloid beta from the human brain. Neuropathol Appl Neurobiol 29:106-117

36. Roberts KF, Elbert DL, Kasten TP, Patterson BW, Sigurdson WC, Connors RE, Ovod V, Munsell LY, Mawuenyega KG, Miller-Thomas MM, Moran CJ, Cross DT 3rd, Derdeyn CP, Bateman RJ (2014) Amyloid-beta efflux from the central nervous system into the plasma. Ann Neurol 76:837-844. doi:10.1002/ ana. 24270

37. Sehgal N, Gupta A, Valli RK, Joshi SD, Mills JT, Hamel E, Khanna P, Jain SC, Thakur SS, Ravindranath V (2012) Withania somnifera reverses Alzheimer's disease pathology by enhancing low-density lipoprotein receptor-related protein in liver. Proc Natl Acad Sci U S A 109:3510-3515. doi:10.1073/ pnas. 1112209109

38. Seliger SL, Siscovick DS, Stehman-Breen CO, Gillen DL, Fitzpatrick A, Bleyer A, Kuller LH (2004) Moderate renal impairment and risk of dementia among older adults: the Cardiovascular Health Cognition Study. J Am Soc Nephrol: JASN 15:1904-1911

39. Shibata M, Yamada S, Kumar SR, Calero M, Bading J, Frangione B, Holtzman DM, Miller CA, Strickland DK, Ghiso J, Zlokovic BV (2000) Clearance of Alzheimer's amyloid-ss(1-40) 
peptide from brain by LDL receptor-related protein-1 at the blood-brain barrier. J Clin Investig 106:1489-1499

40. Silverberg GD, Mayo M, Saul T, Rubenstein E, McGuire D (2003) Alzheimer's disease, normal-pressure hydrocephalus, and senescent changes in CSF circulatory physiology: a hypothesis. Lancet Neurol 2:506-511

41. Tarasoff-Conway JM, Carare RO, Osorio RS, Glodzik L, Butler T, Fieremans E, Axel L, Rusinek H, Nicholson C, Zlokovic BV, Frangione B, Blennow K, Menard J, Zetterberg H, Wisniewski T, de Leon MJ (2015) Clearance systems in the brain-implications for Alzheimer disease. Nat Rev Neurol 11:457-470. doi:10.1038/nrneurol.2015.119

42. Villeda SA, Luo J, Mosher KI, Zou B, Britschgi M, Bieri G, Stan TM, Fainberg N, Ding Z, Eggel A, Lucin KM, Czirr E, Park JS, Couillard-Despres S, Aigner L, Li G, Peskind ER, Kaye JA, Quinn JF, Galasko DR, Xie XS, Rando TA, Wyss-Coray T (2011) The ageing systemic milieu negatively regulates neurogenesis and cognitive function. Nature 477:90-94. doi:10.1038/ nature 10357

43. Villeda SA, Plambeck KE, Middeldorp J, Castellano JM, Mosher KI, Luo J, Smith LK, Bieri G, Lin K, Berdnik D, Wabl R, Udeochu J, Wheatley EG, Zou B, Simmons DA, Xie XS, Longo FM, Wyss-Coray T (2014) Young blood reverses age-related impairments in cognitive function and synaptic plasticity in mice. Nat Med 20:659-663. doi:10.1038/nm.3569

44. Walker JR, Pacoma R, Watson J, Ou W, Alves J, Mason DE, Peters EC, Urbina HD, Welzel G, Althage A, Liu B, Tuntland T, Jacobson LH, Harris JL, Schumacher AM (2013) Enhanced proteolytic clearance of plasma Abeta by peripherally administered neprilysin does not result in reduced levels of brain Abeta in mice. J Neurosci: Off J Soc Neurosci 33:2457-2464. doi:10.1523/JNEUROSCI.3407-12.2013

45. Wang YJ (2014) Alzheimer disease: lessons from immunotherapy for Alzheimer disease. Nat Rev Neurol 10:188-189. doi:10.1038/nrneurol.2014.44
46. Wang YJ, Pollard A, Zhong JH, Dong XY, Wu XB, Zhou HD, Zhou XF (2009) Intramuscular delivery of a single chain antibody gene reduces brain Abeta burden in a mouse model of Alzheimer's disease. Neurobiol Aging 30:364-376. doi:10.1016/j. neurobiolaging.2007.06.013

47. Wang YJ, Zhou HD, Zhou XF (2006) Clearance of amyloid-beta in Alzheimer's disease: progress, problems and perspectives. Drug Discov Today 11:931-938

48. Wilcock DM, Gordon MN, Morgan D (2006) Quantification of cerebral amyloid angiopathy and parenchymal amyloid plaques with Congo red histochemical stain. Nat Protoc 1:1591-1595. doi:10.1038/nprot.2006.277

49. Yamada K, Yabuki C, Seubert P, Schenk D, Hori Y, Ohtsuki S, Terasaki T, Hashimoto T, Iwatsubo T (2009) Abeta immunotherapy: intracerebral sequestration of Abeta by an anti-Abeta monoclonal antibody 266 with high affinity to soluble Abeta. J Neurosci: Off J Soc Neurosci 29:11393-11398. doi:10.1523/ JNEUROSCI.2021-09.2009

50. Yao XQ, Jiao SS, Saadipour K, Zeng F, Wang QH, Zhu C, Shen LL, Zeng GH, Liang CR, Wang J, Liu YH, Hou HY, Xu X, Su YP, Fan XT, Xiao HL, Lue LF, Zeng YQ, Giunta B, Zhong JH, Walker DG, Zhou HD, Tan J, Zhou XF, Wang YJ (2015) p75NTR ectodomain is a physiological neuroprotective molecule against amyloid-beta toxicity in the brain of Alzheimer's disease. Mol Psychiatry. doi:10.1038/mp.2015.49

51. Zeng F, Lu JJ, Zhou XF, Wang YJ (2011) Roles of p75NTR in the pathogenesis of Alzheimer's disease: a novel therapeutic target. Biochem Pharmacol 82:1500-1509. doi:10.1016/j. bcp.2011.06.040 